\title{
Just undiscovered or invasive? The first record of a chiton (Mollusca: Polyplacophora) from the remote Ascension Island, southern Atlantic Ocean
}

\author{
ENRICO SCHWABE ${ }^{1}$ AND KONSTANTINOS TSIAMIS ${ }^{2}$ \\ ${ }^{1}$ Bavarian State Collection of Zoology, Münchhausenstrasse 21, D-81247 München, Germany, ${ }^{2}$ Hellenic Centre for Marine Research \\ (HCMR), Institute of Oceanography, Anavyssos 19013, Attica, Greece
}

\begin{abstract}
During a recent expedition to Ascension Island in the southern Atlantic Ocean, a polyplacophoran of the genus Acanthochitona was collected, corresponding to the first recorded species of this molluscan class from this remote island. A scanning electron microscope study reveals a close affinity to Acanthochitona subrubicunda, which was so far only known from the Cape Verde Archipelago. Due to the lack of comparable type material the new finding warrants a confirmed identification and is only tentatively attributed to Acanthochitona subrubicunda. It is hypothesized that the class Polyplacophora was either overlooked during earlier surveys or colonized the island in more recent time. If the latter scenario took place, a transport by ships is thinkable.
\end{abstract}

Keywords: Mollusca, Polyplacophora, Acanthochitona, Atlantic Ocean, scanning electron microscope study, benthic, zoogeography

Submitted 15 January 2014; accepted 3 July 2014; first published online 14 August 2014

\section{INTRODUCTION}

Polyplacophora, commonly called chitons, are a group of exclusively marine benthic molluscs with a worldwide distribution from the intertidal zone down to hadal depths. Inhabiting all kind of hard substrata they can be found on practically every coast. Despite their simple accessibility, at least in shallow water, so far only about $950(+)$ living species have been described (Schwabe, 2010), make chitons a lesser diverse class of molluscs. It has been shown several times (e.g. Schwabe, 2006; Schwabe et al., 2008; Dell'Angelo et al., 2010; Sirenko, 2012) that with an enhanced sample effort regional species numbers can increase drastically, demonstrating that chitons are often under-represented during malaco-faunistic surveys. Thus, it is not too surprising that in the compiled molluscan list (89 species) of Ascension Island by Rosewater (1975) not a single chiton species was mentioned.

The isolated location of Ascension Island makes the region an attractive object for zoogeographical examinations. The island lies nearly axial on the southern equatorial part of the MidAtlantic Ridge and is thus flanked by two deep-sea basins: the Angola basin to the east; and the Brazilian basin to the west. The nearest land is the slightly larger St Helena island, which lies about $1130 \mathrm{~km}$ south-east. Nearly $1000 \mathrm{~km}$ closer to the West African coast than to the Brazilian coast, the island is located within the influence of the South Equatorial Current (Irving, 1989). For detailed information about the geography and the geological age, we refer to Ashmole \& Ashmole (1997) or a summary review in Irving (2013).

During a recent (2012) expedition to Ascension Island conducted by the Shallow Marine Surveys Group (SMSG) and the South Atlantic Environmental Research Institute (SAERI) several biotas were collected and photographed in the field, which are partly the subject of the present special volume.

Among them, a single species of polyplacophora was collected and is described morphologically here.

\section{MATERIALS AND METHODS}

The specimens at hand were collected as a side effect during the investigation of shallow water phytobenthos. Samples were gained by SCUBA diving (K.T. and Peter Wirtz) down to $30 \mathrm{~m}$ depth, and photographed prior to fixation. Chitons, which were found attached on coralline algae, were sent to the Bavarian State Collection of Zoology, Munich (ZSM) for identification and final storage.

Terminology for species description as well as the preparation techniques for visualization follows Schwabe (2010), radula characters are combined from Saito (2004) and Schwabe (2010) while the systematic depends upon Sirenko (2006).

\section{Taxonomy}

SYSTEMATICS

Corresponding author:

E. Schwabe

Email: enrico.schwabe@zsm.mwn.de
Class POLYPLACOPHORA Gray, 1821 Subclass NEOLORICATA Bergenhayn, 1955 
Order CHITONIDA Thiele, 1909

Suborder ACANTHOCHITONINA Bergenhayn, 1930 Superfamily CRYPTOPLACOIDEA H. \& A. Adams, 1858

Family ACANTHOCHITONIDAE Pilsbry, 1893

Genus Acanthochitona Gray, 1821

\section{TYPE SPECIES}

Chiton fascicularis Linnaeus, 1767 , by monotypy.

\section{GENUS DISTRIBUTION}

Worldwide except for Polar Regions. Oligocene-Recent.

Acanthochitona cf. subrubicunda Leloup, 1941

(Figures 1-4)

Acanthochiton subrubicundus: Leloup, 1941, p. 13, text figure 5, pl. 1, figure 3; Leloup, 1968, p. 74, figure $14 \mathrm{~N}$ (in synonymy of Acanthochitona gracilis (Jeffreys, 1859)); Kaas \& Van Belle, 1980, p. 127.

Acanthochiton(a) subrubicunda(-us): Kaas, 1985, p. 601, figures 91-92 (emendation); Kaas, 1991, p. 95; Kaas \& Van Belle, 1998, p. 181; Strack, 2005, p. 31.
TYPE MATERIAL

Originally described on three syntypes, which should be deposited in the Royal Belgian Institute of Natural Sciences (RBINS) (but see Remarks).

\section{MATERIAL EXAMINED}

ZSM Mol 20130027: 10 specimens from Ascension Island, Horseshoe Reef $\left(7^{\circ} 54^{\prime} 47.8^{\prime \prime} \mathrm{S} 14^{\circ} 24^{\prime} 16.5^{\prime \prime} \mathrm{W}\right)$, on the towerforming coralline red algae Lithophyllum sp., down to $30 \mathrm{~m}$.

\section{DESCRIPTION}

Animal of small size, largest animal examined (Figure 1A-C) slightly curled, measuring $5.3 \times 3.3 \mathrm{~mm}$. Specimen used for scanning electron microscopy (SEM) strongly curled about $4.8 \times 3 \mathrm{~mm}$ (Figures 2-4). Coloration variable, generally comprising reddish tones, from bright pinkish to brown, often interspersed with white freckles. Body outline elongate oval (Figure 1A, C), dorsally subcarinated, high elevated, dorsal elevation quotient of valve II: 0.53 (Figure $2 \mathrm{D}$ ).

Valves quite solid, with only a thin tegmental layer. Head valve (Figure 2A, B) semicircular, anterior slope convex,
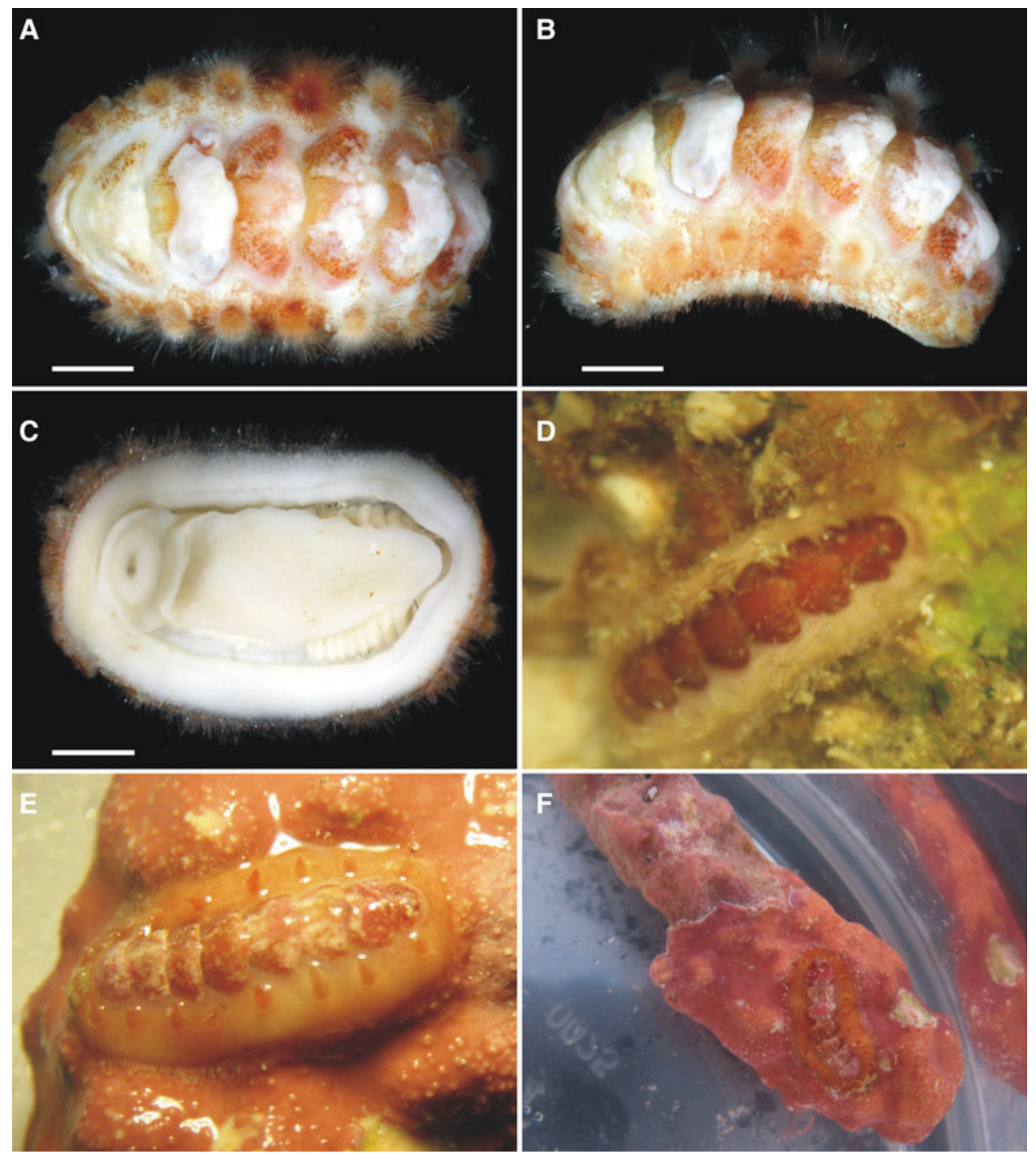

Fig. 1. Acanthochitona cf. subrubicunda Leloup, 1941: (A) dorsal view of a preserved specimen; (B) dorso-lateral view of same specimen; (C) ventral view of same specimen; (D-F) in situ images on the coralline red algae Lithophyllum sp., prior to fixation. Scale bars: A-C, $1 \mathrm{~mm}$; D-F, scale unknown. 

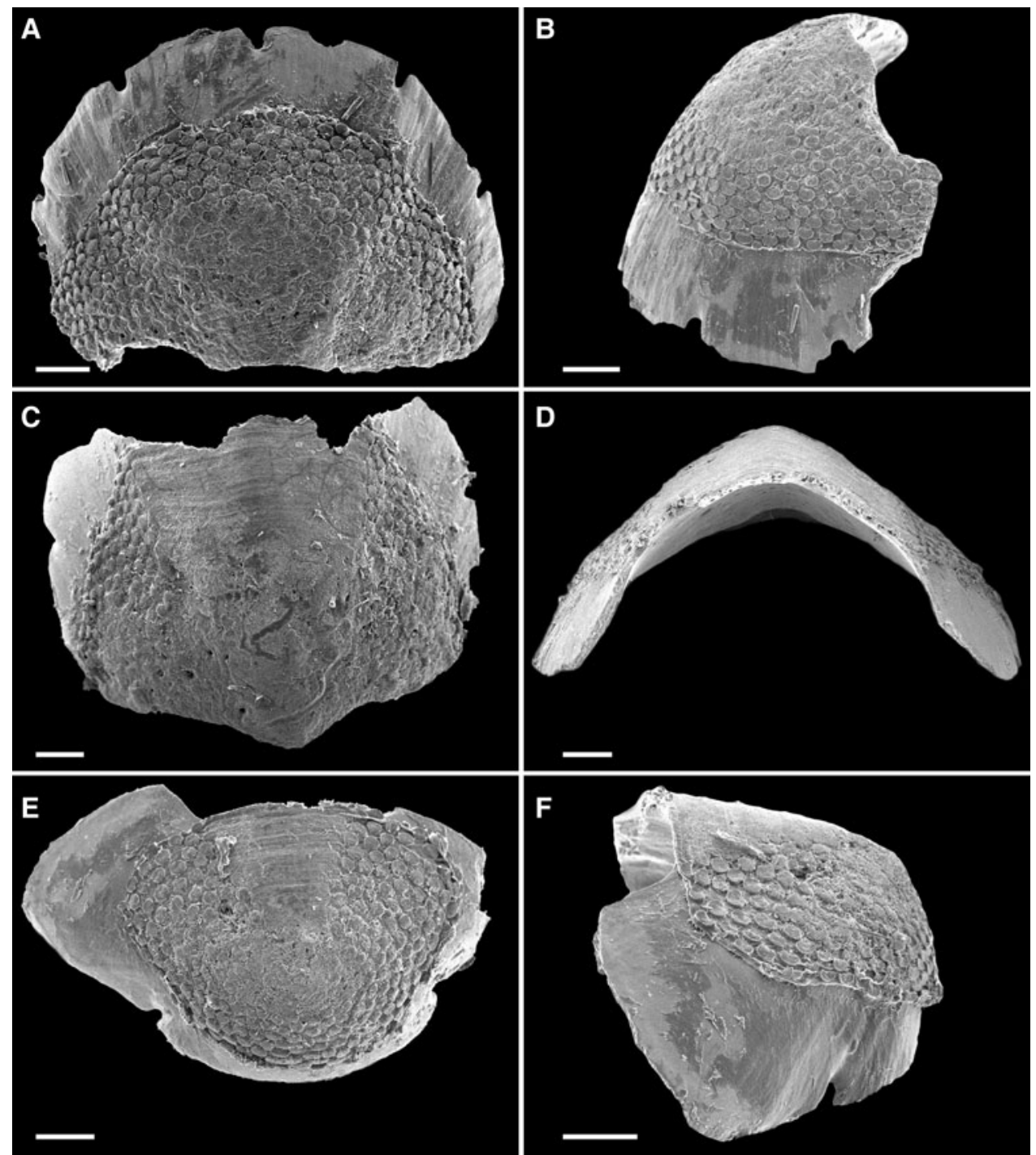

Fig. 2. Scanning electron microscopy images of Acanthochitona cf. subrubicunda Leloup, 1941: (A) dorsal view of head valve; (B) lateral view of head valve; (C) dorsal view of valve II; (D) frontal view of valve II; (E) dorsal view of tail valve; (F) lateral view of tail valve. All scale bars $200 \mu \mathrm{m}$.

posterior margin straight. Intermediate valves (Figure $2 \mathrm{C}, \mathrm{D}$ ) rhomboid, with clearly protruding apical area, resulting in a plectrum-like shape. Tegmental layer of intermediate valves anteriorly less wide than posterior. Tail valve (Figure $2 \mathrm{E}, \mathrm{F}$ ) more or less circular, but tegmentum anteriorly clearly wider than posterior. Mucro situated at the posterior third, slightly forward directed, postmucronal slope steep and straight, antemucronal area straight.

Tegmentum (Figure $3 \mathrm{~A}-\mathrm{D}$ ) comprises minute, round to slightly drop-shaped, slightly elevated granules, about $50 \mu \mathrm{m}$ in diameter. Granules surface centrally depressed with a slightly elevated megalaesthete, posteriorly the granule slopes to the valve surface, forming a shallow furrow. Micraesthetes not discernible. Granules arranged in quincunx in head valve, pleurolateral areas of valves II - VIII and postmucronal area. Intermediate valves and tail valve with broad wedge-shaped, smooth jugal area, although light microscopic examination allows a look on underlying nerve channels, given the jugal area a striated appearance. Eaves with a single channel layer only.

Articulamentum solid, shining, central parts reddish to pinkish, fading towards the outsides. Jugal tract of intermediate valves porous, slit rays shining through, otherwise hardly visible, not perforated. Insertion plates (Figure 2A-C, E, F) large, with sharp edges, smooth, incisions deep. Slit formula: 5/1/2. Central callus deeply depressed. Ventral tegmental callus quite extended. Apophyses large, laterally extended, wing-shaped in intermediate valves and rectangular in tail valve.

Radula of a specimen measuring about $4.8 \times 3 \mathrm{~mm}$, about $2.5 \mathrm{~mm}$ in length, anteriormost $1.6 \mathrm{~mm}$ underlying by cartilages. Radula (Figure ${ }_{3} \mathrm{E}, \mathrm{F}$ ) with 43 transversal teeth rows, with 36 rows already mineralized. Central tooth (Figure ${ }_{3} \mathrm{~F}$ ) slender, tulip-shaped, slightly embayed at the middle, about $36 \mu \mathrm{m}$ in length and $17 \mu \mathrm{m}$ wide at the strongly keeled base. Blade simple with a posteriorly folded projecting process. First lateral tooth (Figure $3 \mathrm{~F}$ ) S-shaped, antero-dorsal corner slightly bent inwards, no accessory process detectable. Second lateral tooth with tricuspidate head, denticles sharppointed, but outer one distinctively wider than inner, central denticle longest. Major uncinal tooth spoon-shaped with slender, cylindrical shaft.

Girdle fleshy, slightly brighter coloured than valves (Figure $1 \mathrm{D}-\mathrm{F}$ ), dorsally with densely arranged bilaterally 

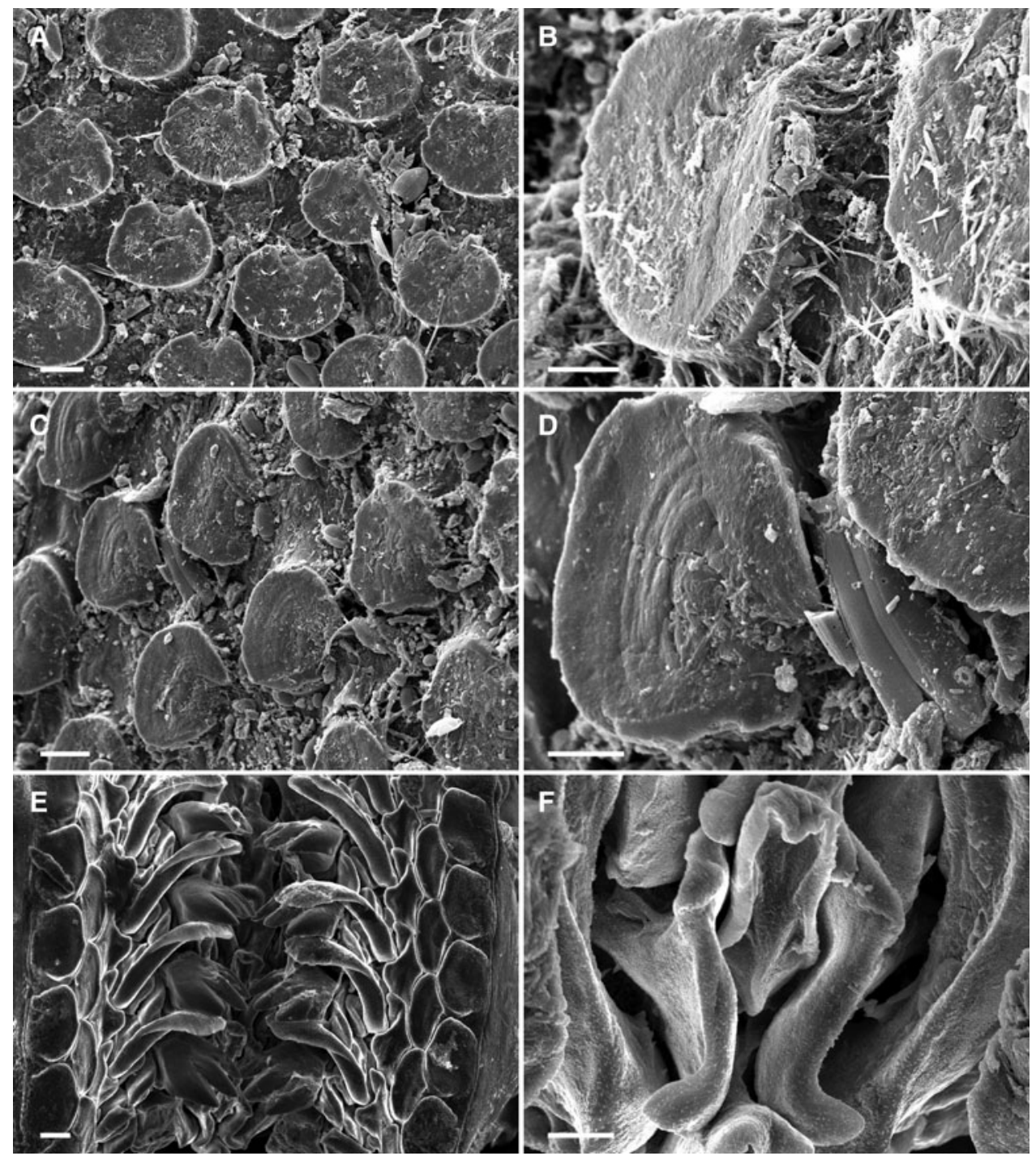

Fig. 3. Scanning electron microscopy images of Acanthochitona cf. subrubicunda Leloup, 1941: (A) granule arrangement at head valve; (B) lateral view of a single granule at head valve; (C) granule arrangement at pleurolateral area of valve II; (D) posterior-dorsal view on a single granule from same region as 'C'; (E) anterior rows of radula; (F) central portion of a single teeth row to show the central tooth and first lateral teeth. Scale bars: $A, C, E, 20 \mu \mathrm{m} ; \mathrm{B}, \mathrm{D}, \mathrm{F}, 10 \mu \mathrm{m}$.

flattened, sharp to obtusely-pointed spicules (Figure $4 \mathrm{Ee}$ ), up to $50 \mu \mathrm{m}$, that show a vague longitudinal striation. Spicules straight, but terminally slightly narrower (Figure 4A). Marginal fringe (Figure $4 \mathrm{C}$ ), dense, with sharppointed, straight to slightly curved spicules (Figure $4 \mathrm{Ec}$ ), measuring up to $350 \times 30 \mu \mathrm{m}$, distinctively coarser longitudinal striated than dorsal spicules. 18 tufts (Figure $4 \mathrm{~B}$ ) arranged typical acanthochitonid over the whole girdle, one at each sutural region and four encircling the anterior valve. Single tuft comprises more than 200 straight, very slender, sharp-pointed needles (Figure $4 \mathrm{Ea}$ ), which may attain a length of nearly half a millimetre (longest measured $417 \mu \mathrm{m})$. Among the needles occur very slender straight, sharp-pointed spines, which may attain a length of up to $180 \mu \mathrm{m}$ (Figure 4Eb). Hyponotum (Figure 4D) with densely arranged, blunt-pointed, bilaterally flattened spicules (Figure $4 \mathrm{Ef}$ ), up to $30 \mu \mathrm{m}$ in length and $10 \mu \mathrm{m}$ in width. They show a micro-perforation on the otherwise smooth surface; whether this is an artefact or belongs to a kind of sculpture remains unclear.
Ctenidia in the largest examined specimen arranged merobranchial, nine per side, with the group of longest being the posterior three (Figure $1 \mathrm{C}$ ).

\section{HABITAT}

The chitons were only found on the surface of the coralline red algae Lithophyllum sp., on which they probably also graze on the biofilm covering the algae (Figure $1 \mathrm{D}-\mathrm{F}$ ). The alga is currently under study (K.T.) for a final identification. Remarkable is the tower-forming growth of this species. It was several times shown that chitons as erosive grazers can (but not exclusively, see Price \& John, 1980) have a massive impact on algae mutualism (e.g. Littler et al., 1995; Littler \& Littler, 1999). Whether Acanthochitona cf. subrubicunda has such an impact to Lithophyllum sp. remains unclear at present. Surprisingly, Price \& John (1980) who characterized the algae composition of Ascension Island did not mention a single chiton.

The collecting locality corresponds to the intersection region of sectors $4-5$ which were defined by Irving (1989) as belonging to the most sheltered sector of the open coast 

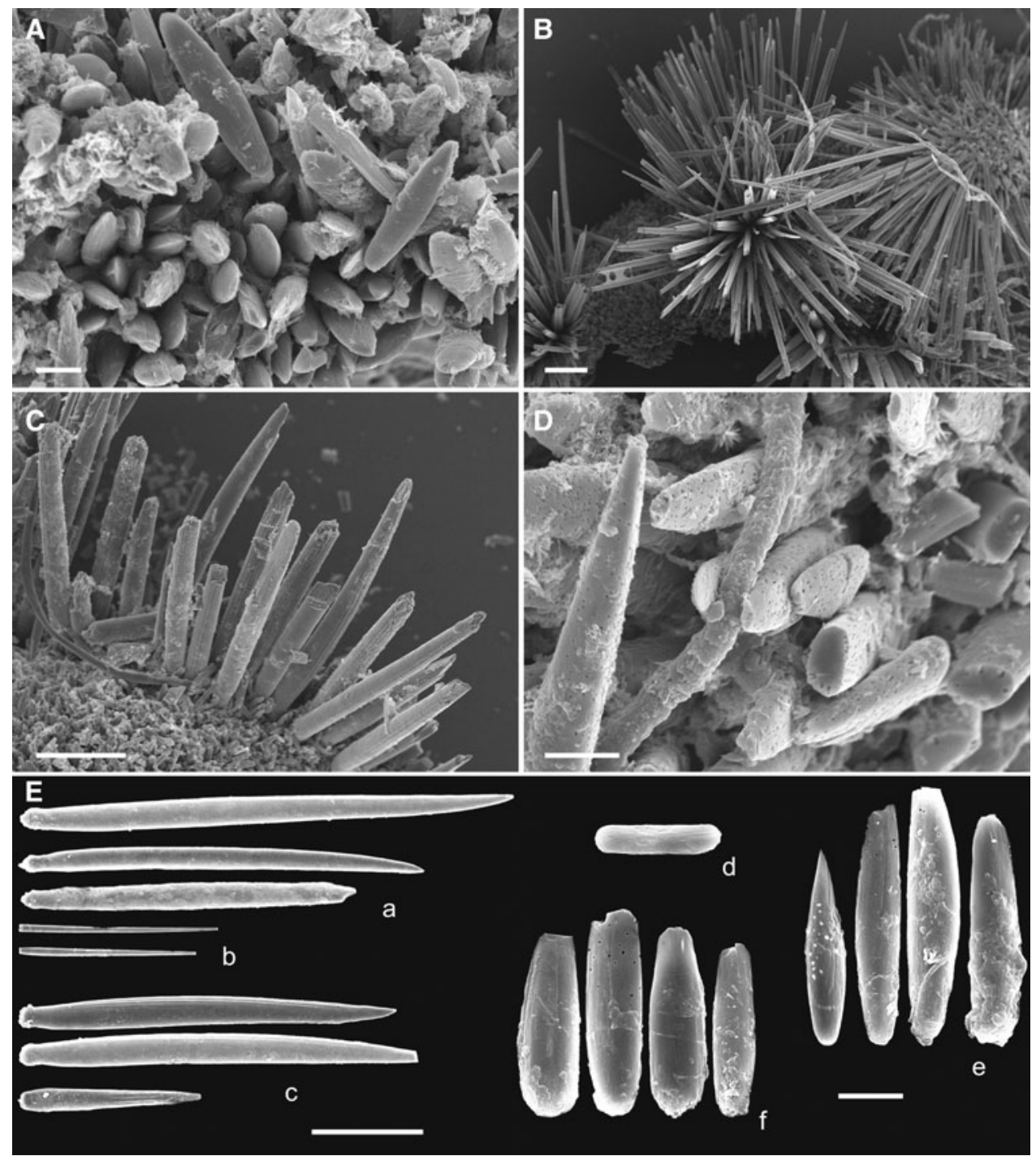

Fig. 4. Scanning electron microscopy images of girdle of Acanthochitona cf. subrubicunda Leloup, 1941, (A-D) in situ, (E) isolated girdle elements: (A) dorsal spicules; (B) tufts; (C) marginal fringe; (D) ventral spicules; (E) a, tuft needles; b, tuft spines; c, marginal spicules; d, dorsal spicule near margin; e, dorsal spicules; f, ventral spicules. Scale bars: A, D, E(d-f), $10 \mu \mathrm{m} ; \mathrm{B}-\mathrm{C}, \mathrm{E}(\mathrm{a}-\mathrm{c}), 100 \mu \mathrm{m}$.

(sector 4) and as biological rich (sector 5), respectively. Both sections share coarse sand and maerl patches.

\section{REMARKS}

The species fits rather well the original description and also the illustration that Kaas (1985) provided of one syntype of A. subrubicundus, except for slight differences in the present girdle elements compared to Leloup's original description. Some of his tuft needles are more curved. Also the ventral spicules are obviously more pointed compared to our material. As we present here data of a single examined specimen only and the original description shows slight variation between the elements of two illustrated specimens, the observed variation may fall in the range of variability of this species.

The syntype series consisting of three specimens should be deposited in the RBINS. However, according to Dr Yves Samyn, who checked the collection on our request, only spicule preparations are available under the name ' $A$. subrubicundus'. Noteworthy, Kaas (1985: figures 91-92) illustrated a syntype of $A$. subrubicunda, but nothing is known about the whereabouts of this specimen. As long as the type material is not traceable and a comparative study impossible, we refer only tentatively to Leloup's species.

\section{DISCUSSIDN}

The by far most isolated island in the Atlantic Ocean is surely Ascension Island. Its young age approximately $1.5 \times 10^{6} \mathrm{yr} \mathrm{BP}$-together with its distances to the next land masses-make it a 'natural laboratory' for the study of small-scale evolution (Ávila, 2013). Regarding the rather long distances to the West African coast (about $1500 \mathrm{~km}$ ), as well as to the South American coast $(2400 \mathrm{~km})$, the nearest land mass that could serve as a colonization source is the geologically older St Helena island. The latter dates back to $20 \times 10^{6} \mathrm{yr} \mathrm{BP}$ and lies about $1130 \mathrm{~km}$ south-east of Ascension Island (Irving, 2013).

Evolutionary pathways might be best shown by direct comparisons between faunistic components of an island and its 
surrounding land masses. Rosewater (1975) made such an attempt for the malaco-fauna and several other authors for additional invertebrates and fish (see references in the present special volume). The author clearly demonstrated that the fauna of marine molluscs at Ascension Island is only $50 \%$ of what is known from St Helena. Ascension, with 89 mollusc species, shares $42 \%$ of its species with St Helena. That leaves the question of the origin of the remaining Ascension species unanswered.

A clear evolutionary pattern is not traceable, as only $9 \%$ of 89 species could be considered endemic, while all other species have a wider distributional range, ranging to both sides of the Atlantic or even the East Pacific and Indian Ocean.

From its geographical position in the upper slope of the north-westward flowing South Equatorial Current (Irving, 1989), one would expect a colonization from the IndoPacific, but Ascension shares only seven species with this region. Also the West African fauna, with $22 \%$ overlapping species, falls behind the western Atlantic, where a slightly higher percentage $(27 \%)$ of Ascension marine molluscs is shared. According to Rosewater (1975) $21 \%$ of the marine molluscs at Ascension occur on both sides of the Atlantic. They should be of special interest as gene flow might show the evolutionary relationship of the involved species. Unfortunately such studies are missing for molluscs and we have to refer to Padula et al. (2017) to substantiate this. Here we present the first chiton ever mentioned from Ascension Island. Making the picture sketched above more intricate, the chiton species mentioned herein is potentially identical to A. subrubicunda, a species previously known from the Cape Verde Archipelago only (Leloup, 1941; Kaas, 1985). Ávila (2013) shows in an exemplary manner the restricted overlapping of some molluscs from Cape Verde Island and Ascension Island, interestingly with representatives of all dispersal types: brooders and species with nonplanktotrophic and planktotrophic larvae. The long distance between island groups and the in-between South Equatorial Current make a direct north-south connection unlikely. The Cape Verde chitons, however, show a considerable high overlapping of $21.4 \%$ with the chiton fauna of the São Tomé and Principe Islands (Dell'Angelo et al., 2014). Hence, one colonization direction of A. subrubicunda could be via the São Tomé and Principe Islands, but so far the species has not been confirmed from this region (Dell'Angelo et al., 2014).

In how far rafting is a hypothetical explanation for the occurrence of $A$. subrubicunda remains unclear until data about the species' reproductive mode are studied or a direct proof for this scenario appears. The possibility, however, was suggested for intertidal invertebrates by Hoeksema et al. (2012).

With the recent single record of a chiton from Ascension Island over a long period of investigation (summary in Irving, 2013, p. 213 ff.) the question arises whether chitons were overlooked in the past or if they have newly invaded Ascension Island. To our best knowledge there is no fossil malaco-faunistic record from Ascension Island. If colonization occurred earlier it might be tested by the examination of lava fields to find tempestites-which may show shallow water habitat conditions during the geological past of the coastline (e.g. Meireles et al., 2013). Noteworthy also is that the geologically older St Helena island also lacks published chiton records. According to Bruno Anseeuw (personal communication) he recently received isolated valves (no live material) of two chiton species, an ischnochitonid species and an acanthochitonid species. Whether the latter belongs to the same species presented in the present study requires further investigations and preferably live collected material.

From the above-mentioned considerations we assume that the chitons could be a result of a recent introduction to Ascension Island, especially as Price \& John (1980) during their phytobenthic examination also did not mention the occurrence of associated chiton species. Such an invasion event could be well explained by ship transport, a scenario which has also been suggested for other chiton species (e.g. Arias \& Anadón, 2013). Adding the new chiton record and seven further new gastropods (Padula et al., 2017) to the previously known species number (Rosewater, 1975) the molluscan fauna of Ascension Island now comprises 97 marine species.

\section{ACKNOWLEDGEMENTS}

Konstantinos Tsiamis is grateful to Paul Brickle and the Shallow Marine Surveys Group for the invitation to take part in the August-September 2012 expedition to Ascension Island. Thanks to Professor Frithjof C. Kuepper for sampling assistance, as well as to Stedson Stroud and Jolene Sim of the Ascension Conservation Department for their help during the expedition. We are grateful to the Shallow Marine Surveys Group and the South Atlantic Environmental Research Institute for organizing the expedition. We are also very grateful to Ascension Island Government, the members of staff at the Conservation Centre and Ascension Island Dive Club for their cooperation, accommodation and hospitality. Finally we are grateful to British Forces South Atlantic Islands for their logistic support. We are grateful to Laura Schwabe (University of Hamburg) and two anonymous referees for critical comments to an earlier version of the manuscript. Peter Wirtz (Portugal) kindly made the present material for a study available.

\section{FINANCIAL SUPPORT}

The funding for this work came from a grant to the Shallow Marine Surveys Group from the Darwin Initiative (EIDCFo12).

\section{REFERENCES}

Arias A. and Anadón N. (2013) Tonicia atrata and Chiton cumingsii (Polyplacophora: Chitonidae): first records in European waters. Zootaxa 3626, 593-596.

Ashmole N.P. and Ashmole M.J. (1997) The land fauna of Ascension Island: new data fromcaves and lava flows, and a reconstruction of the prehistoric ecosystem. Journal of Biogeography 24, 549-589.

Ávila S.P. (2013) Unravelling the patterns and processes of evolution of marine life in oceanic islands: a global framework. In Fernánez-Palacios J.M., Nascimento L., Hernández J.C., Clemente S., González A. and Díaz-González J.P. (eds) Climate change perspectives from the Atlantic: past, present and future. Tenerife: Universidad de La Laguna, pp. 85-115. 
Dell'Angelo B., Gori S., Baschieri L. and Bonfitto A. (2010) Chitons (Mollusca, Polyplacophora) from the Maldive Islands. Zootaxa 2673, $1-38$.

Dell'Angelo B., Schwabe E., Gori S., Sosso M. and Bonfitto A. (2014) Chitons (Mollusca, Polyplacophora) from São Tomé and Principe Islands. African Invertebrates. 55, 171-200.

Hoeksema B.W., Roos P.J. and Cadée G.C. (2012) Trans-Atlantic rafting by the brooding reef coral Favia fragum on man-made flotsam. Marine Ecology Progress Series 445, 209-218.

Irving R.A. (1989) A preliminary investigation of the sublittoral habitats and communities of Ascension Island, South Atlantic. Progress in Underwater Science 13, 65-78.

Irving R.A. (2013) Ascension Island's hermatypic but non-reef building corals. In Sheppard C.R.C. (ed.) Coral reefs of the United Kingdom Overseas Territories-Coral Reefs of the World 4. Dordrecht: Springer, pp. 213-221.

Kaas P. (1985) The genus Acanthochitona Gray, 1821 (Mollusca, Polyplacophora) in the north-eastern Atlantic ocean and in the Mediterranean Sea, with designation of neotypes of A. fascicularis (L., 1767) and of A. crinita (Pennant, 1777). Bulletin du Muséum national d'Histoire Naturelle, section A Series 4 7, 579-609.

Kaas P. (1991) Chitons (Mollusca: Polyplacophora) procured by the CANCAP I-VII expeditions, 1976-86. Zoologische Mededelingen 65 $89-98$.

Kaas P. and Van Belle R.A. (1980) Catalogue of living chitons (Mollusca: Polyplacophora). Rotterdam: Dr W. Backhuys Publisher.

Kaas P. and Van Belle R.A. (1998) Catalogue of living chitons (Mollusca Polyplacophora). 2nd revised edition. Leiden: W. Backhyus Publishers.

Leloup E. (1941) A propos de quelques Acanthochitons peu connus ou nouveaux II-région Atlantique. Bulletin de l'Institut Royal des Sciences Naturelles de Belgique 17, 1-15.

Leloup E. (1968) Acanthochitons de la côte Atlantique Africaine. Memórias da Junta de Investigaçôes do Ultramar 54, 55-84, figs 1-21.

Littler M.M. and Littler D.S. (1999) Castles built by a chiton from the Great Astrolabe Reef, Fiji. Coral Reef 18, 158.

Littler M.M., Littler D.S. and Taylor P.R. (1995) Selective herbivore increases biomass of its prey: a chiton-coralline reef-building association. Ecology 76, 1666-1681.
Meireles R.P., Quartau R., Ramalho R.S., Rebelo A.C., Madeira J., Zanon V. and Ávila S.P. (2013) Depositional processes on oceanic island shelves-evidence from storm-generated Neogene deposits from the mid-North Atlantic. Sedimentology 60, 1769-1785.

Padula V., Wirtz P. and Schrödl M. (2017) Heterobranch sea slugs (Mollusca: Gastropoda) from Ascension Island (South Atlantic). Journal of the Marine Biological Association of the United Kingdom 97, 743-752.

Price H. and John D.M. (1980) Ascension Island, South Atlantic: a survey of inshore benthic macroorganisms, communities and interactions. Aquatic Botany 9, 251-278.

Rosewater J. (1975) An annotated list of the marine mollusks of Ascension Island, South Atlantic Ocean. Smithsonian Contributions to Zoology 189, 1-41.

Saito H. (2004) Phylogenetic significance of the radula in chitons, with special reference to the Cryptoplacoidea (Mollusca: Polyplacophora). Bollettino Malacologico 39 (Supplement 5), 83-104.

Schwabe E. (2006) On a small collection of chitons from Papua New Guinea (Mollusca: Polyplacophora). Venus 65, 97-112.

Schwabe E. (2010) Illustrated summary of chiton terminology (Mollusca, Polyplacophora). Spixiana 33, 171-194.

Schwabe E., Sirenko B.I. and Seeto J. (2008) A checklist of Polyplacophora (Mollusca) from the Fiji islands. Zootaxa 1777, 1-52.

Sirenko B.I. (2006) New outlook on the system of chitons (Mollusca: Polyplacophora). Venus 65, 27-49.

Sirenko B.I. (2012) Chitons (Mollusca, Polyplacophora) of Nhatrang Bay, South Vietnam. In Britayev T.A. and Pavlov D.S. (eds) Benthic fauna of the Bay of Nhatrang, Southern Vietnam, Volume 2. Moscow: KMK Scientific Press Ltd., pp. 56-122.

and

Strack H.L. (2005) Polyplacophora. In Rolán E. (ed.) Malacological fauna from the Cape Verde Archipelago. Part 1. Polyplacophora and Gastropoda. Hackenheim: ConchBooks, pp. 27-31.

\section{Correspondence should be addressed to:}

E. Schwabe

Bavarian State collection of Zoology

Münchhausenstrasse 21, D-81247 München, Germany

email: enrico.schwabe@zsm.mwn.de 